\title{
Sir James Black (1924-2010) reflections
}

\section{Adam Cohen, Professor of Clinical Pharma- cology, Leiden University Medical Centre}

Jim was head of pharmacology when I worked for Tony Peck as a trainee clinical pharmacologist on lamotrigine (Lamictal). This antiepileptic was discovered entirely by accident and its research was based upon the hypothesis that all antiepileptics were antifolate agents. This hypothesis was proven wrong when lamotrigine was found to be a very potent antiepileptic without any anifolate properties. I think Jim disliked the old fashioned and irrational way this pretty useful drug was found, as he was the obvious proponent of rational drug design. I vividly remember our discussions about concepts which at the time were new. He was fully aware in 1985 that one would need rapid and reliable markers for pharmacodynamics of a drug and that it would be impossible to rely upon long and costly clinical trials alone. These logical thought processes are still considered innovative now.

We kept meeting after he and I left Wellcome and he was one of the discussants (with Paul Jansen and other great drug hunters) in the first of our Leiden Dinosaur meetings about the future of the pharmaceutical industry. In the preparations for this I visited the Half Moon Lane lab where we talked amongst running experiments and Jim used to jump up in the middle of the meeting to review some recent experimental results. Most recently we talked about the TGN1412 disaster when he rang me up to express his horror about the development of this drug without any pharmacological insight.

Jim exuded energy, enthusiasm and positive thinking and these properties were infectious. A meeting with Jim left you with a good feeling, new ideas and energy to go on. Without Jim we will have to find other examples and hopefully follow his lead in inspiring other young colleagues, but it will be a hard act to follow! It was a privilege to have known him.

\section{Gordon Baxter}

Sir James advised, encouraged and occasionally cautioned me when I left big pharma to establish Pharmagene in 1996. I am still hugely inspired by what he achieved as a drug hunter but also by the work he published, with Paul Leff, on the Operational Model of Agonism. His perspective opened my eyes to the potential of the enlightened pharmacologist. Sir James also lectured my father at Glasgow Veterinary School. He remembers two quotes from his year- book, both of which I sent to James a decade ago. Of James Black "There is no such thing as genius without some hint of madness" and "A man with both feet planted firmly in mid air".

A great man and a sad loss.

\section{Steve Watson}

It is with great sadness that I have heard the news about Sir James Black.

My own recollection of Sir James is that of a very warm person with terrific enthusiasm and a firm belief in experimentation. He made me smile when he said that he always asked a PhD student to begin a project by repeating a previous line of work, as they would always get a different result!

He will be enormously missed by the community.

\section{Craig J Daly}

I first met Sir James (a hard act to follow) whilst we were switching laptops in a Washington DC conference hall. I took the opportunity to invite him to Glasgow to talk to our students. He agreed on the proviso that there would be no 'suits', no limousines, no red carpet treatment and NO STAFF! True to his word, Sir James arrived a few months later and gave 2 lectures to two different groups of 'starryeyed' students. Sir James then attended a cheese and wine and spent the bulk of the time mixing with students before quietly slipping away into the night; and back to London. Professor Sir James Black was a wonderful example to academics both young and old.

\section{Graeme Henderson}

My 'recollection' of Sir James.

I treasure an email sent to me by Sir James in 2005 which just read

'Bless you!'

We had been in correspondence about Sir James' mentor in research, Prof. R.C. Garry who had also taught me Physiology at the University of Glasgow and I had recalled an amusing anecdote about Garry hoodwinking the external examiner during my viva and preventing me from continuing with what had been the wrong answer to a fairly basic question.

It is just a pity that we are now in the age of email correspondence. If I had received Sir James' message as a signed note it would now be framed and proudly displayed on my office wall. 


\section{Geoff Burnstock}

James Black was an exceptional scientist and a wonderful human being. He was especially supportive of offbeat characters, who he believed to be original.

\section{Hugh Clements-Jewery}

I had the enormous privilege of meeting Sir James at a dinner in Vancouver (Joint BPS meeting) in 2001. As a fresh-faced Ph.D. student at the time I did not quite appreciate the significance of meeting him, but one other person at the dinner told me at the time that in years to come, I would look back on that moment fondly. He was right. I did not know Sir James Black well, but I do feel honoured to have met and talked with one of the greatest individuals in the history of pharmacology.

\section{Piero Schiantarelli}

I met James Black in Pisa in 1975, when I was the director of the pharmacological department in a small pharmaceutical company in Tuscany. Black was obtaining considerable results with the histamine- 2 antagonists burimamide and metiamide. As were several other companies at the time, we were also enthusiastically involved in the search for new molecules of this new class of gastric antisecretory drugs, which appeared to be so effective as to promise an end to gastric ulcer surgery. James Black was kind enough to accept our invitation to evaluate some of the data obtained in our labs. What I remember most about this encounter was his simplicity and affability, which helped dispel my trepidation as a young pharmacologist.

Farewell, James!

\section{David E Clarke}

Jim Black was more than a pharmacologist and Nobel Prize winner. He possessed one of the most, if not the most, important attributes a human being can possess: empathy.

After a morning of science in the kitchen of his "house", we went out for lunch at a pub. Walking side by side back along the street, deep in conversation, he suddenly jumped into the road, and ran over to the other side. There stood an old woman, fearful of crossing the road. He took her hand, and with one arm behind her back, he led her safely to my side of the road. He rejoined me, and without a break in his train of thought, continued with our scientific conversation. We never mentioned the woman, ever. No need, it was the right thing to do.

\section{Jeffrey S. Fedan}

It is impossible as a pharmacologist not to have been influenced by this titan's courage, insights and con- tributions. In this era of "translational" medicine, one would have difficulty identifying a more important pioneer and model.

God Speed, Sir James.

\section{Helge L. Waldum}

Among the great scientists I have met during my career, I have appreciated Sir James Black highest. He was a great man not only in science, but also as a person. He was so natural, and although there was a gap between his reputation and mine, I always felt close to him. At congresses and meetings we often spent some time together. In a way, he was an outsider (like me).

He visited Trondheim twice; the last time in 2006 for my birthday, where he made a presentation not about what he had done, but about a new group of drugs, gastrin receptor antagonists that he was working on. In November he invited me to a lunch in London, and we had an appointment in December. Two days before the scheduled day he broke his hip.

I am very grateful to have met and learned to know Sir James Black.

My condolences go to his wife and family.

Edmund Neugebauer (Chair for Surgical Research, University Witten/Herdecke, Germany) Sir James Black, as person and scientist, will stay in our memories forever. My personal contact was about $\mathrm{H}_{2}$-receptors and antagonists with lots of scientific discussions and personal advice for my own career. We have lost a great personality.

\section{Adesuyi Ajayi}

Words are insufficient to express the impact of Sir James's Life, and now his passing on the world!

He was an inspiration to all young physicianscientists, and a hero in the war against common human diseases on a global scale. His impact was prodigious, and is of the order of magnitude of what it takes several life times or generations to accomplish.

The therapeutic products of his scientific actions impacted virtually all body systems, and improved our understanding of pharmacodynamics and the new frontier of pharmacogenomics.

I urge the society to establish a biography/biopic of this titan of men (and such like him) to be broadcast on Television (Discovery channel) to inspire even greater number of young scientists around the world. The world needs more James Blacks and that is the fitting and best tribute he deserves. His imperishable works shall remain, and his giant imprints on the sands of time is a challenge to forthcoming generations. He was a model of great genius and even greater humility! 
I always dreamed of growing up to be like Sir James Black, and I and the world shall NEVER forget him!!!!

Ken Wann Welsh School of Pharmacy, Cardiff I had the good fortune to meet Sir James Black when we both worked at the Wellcome Foundation in Beckenham. I subsequently worked with him briefly at the James Black Foundation where I would have the particular extra good fortune to enjoy an occasional lunchtime beer and his company. Since we both have strong links with St Andrews, Jim having graduated in Medicine from there, and it being my birthplace, we touched on the subject of golf from time to time although we had quite different views on the subject.

Having not crossed paths in some time, we were sitting talking casually at a Pharmaceutical Society meeting in McEwan Hall in Edinburgh one Sunday morning about 10 years back, Jim typically with tie loosened, jacket off and sleeves rolled up, when a young man came up and enquired whether either of us was the slide projectionist. I said I was happy to do the job, but my companion certainly could not since he was the Plenary speaker whose talk we were about to listen to!

Last year Jim phoned me in response to an invitation from our Welsh School of Pharmacy Postgraduate Society to their Summer "Great Minds" seminar series. On this occasion I mistook him for the man who was doing an MOT that day on my car since I was awaiting his call. Jim however was calling to apologize for not responding to my student's invitation to speak. He said he would be too embarrassed to speak at a seminar series that had such a title. Such was the modesty of the man. I offered to change it to "Great Bodies" at which he chortled "Great Laughs more like". He said I might entice him to come through to talk to the students informally, particularly if there was rugby on, or something suitable at the Millennium Centre in Cardiff. This was not however to be.

\section{Rod Flower}

I first met Jim in the late 1960s. He came to the Department of Pharmacology in the Royal College of Surgeons to do some experiments, with John Vane, investigating the fate of histamine in vivo. I was responsible for setting up John's rather complex blood bathed organ cascade for this work. Although I was only a technician then, Jim questioned me closely about the technique and paid careful attention to everything I had to say although he challenged everything and left me nowhere to hide if my answer didn't satisfy him!
During my subsequent career, my many encounters with him confirmed his fierce intelligence. But I also discovered another side to him; he was a charming and entertaining social companion, and I recall many happy evenings spent in his company at professional dinners and other events .

His legacy - both in terms of the ideas and drugs he pioneered as well as the scientists he trained will enrich our discipline for many years to come and serve as a continuing source of inspiration to future pharmacologists.

David J Kroll, PhD North Carolina Central University Durham NC, USA

In May 1985, Sir James was to speak at the commencement exercises for the Philadelphia College of Pharmacy and Science where I would be awarded my BS in Pharmacology and Toxicology. While noteworthy as the first US college of pharmacy, established in 1821, the school was relatively small with only 175 graduates that year. Therefore, it was an even greater honour that a scientist of Sir James's stature would agree to address such a small group. I suspect that the offer by the Board of Trustees to bring Sir James over on the Concorde played into his decision to speak.

Philadelphia was also home to what was then SmithKline \& French Laboratories, where I had been fortunate to complete a research internship in drug metabolism during my junior and senior years. Given Sir James's history with the UK side of the organization, his speech carried even greater meaning for me. I had learned firsthand just how monumental a task it was to bring one just drug to market. For a man to be responsible for bringing two drugs to market was amazing; for each to be a firstin-class therapeutic was beyond comprehension. My colleagues and I would be in the presence of true pharmacological greatness, a living ambassador of our field.

Success in both industry and academia was unusual for the time so I was interested to learn which Sir James found most important. To my surprise, he spent most of his address singing the praises of basic research, research for research's sake. Noting that he would have been nowhere without the 1948 American Journal of Physiology work of Raymond Ahlquist at the University of Georgia, Sir James stressed that those of us continuing in research careers should focus on the questions most interesting regardless of whether a commercial opportunity could be foreseen from our work. To hear such a message from a master of drug discovery and development was a revelation and one that has stayed with me throughout my career. Even in his 2001 Nobel Foundation interview, Sir James decried 
the movement of research universities toward disproportionate focus on intellectual property generation and evaluating faculty members more on the commercial potential of their work rather than their contributions to our foundation of knowledge. Sir James recognized decades ago that industry and academia should each focus on the strengths for which they were best-suited.

When I became an assistant professor in Denver, I drew again on the example of Sir James which instilled in me early the need for interdependence with my chemistry colleagues. Collaborations in pharmacognosy and medicinal chemistry have been essential to my career and have provided wellrounded experiences for my students. Sir James even inspired my efforts in pharmacology education of the general public: the chemistry of the development of cimetidine from histamine was so elegant yet approachable that I used the example each year in the Mini-Med School sessions I would teach to lay audiences at the University of Colorado.

As I write this remembrance from North Carolina, I recall my other inspirations who shared with Sir James the 1988 Nobel Prize in Physiology or Medicine, Trudy Elion and George Hitchings. Although they worked in cancer and other therapeutic areas, these scientists had in common with Sir James the idea of rational drug design beginning with the structures of endogenous compounds, creating selective therapeutic analogs that extended the lives of millions.

Unfortunately, I never had the opportunity to know Sir James personally. However, the impact he has made on me and my career leads me to think that his loss is immeasurable to those who knew and loved him. I extend my condolences to his valued colleagues of the British Pharmacological Society and, most of all, to Professor MacKie and the family.

\section{Terry Kenakin}

Sir James had come over to Research Triangle Park North Carolina in 1978 to meet senior scientists of Burroughs Wellcome; he had recently been appointed head of Wellcome worldwide. Since I had been his post doctoral fellow at University College London for the past 3 years, I was his designated chauffeur for the evening. As we left the Angus Barn, a local eatery, after considerable merriment, I asked Sir James ... ' 'how was it you came to settle on such important and 'Nobel-sized' problems in your career ... his answer was typically honest and self effacing...'All I knew was that dichloroisoproterenol partially blocked isoproterenol ... and it confounded me... I just followed a wee little problem'

\section{Richard A. Bond}

In the mid 1990's I was walking with Sir James at a scientific congress in San Diego. A very distinguished scientist approached us and said, 'Jim, I need 30 minutes of your time to discuss some things with you'. To which Sir James politely replied, 'of course, please have your secretary contact my office and we will schedule it'. We walked along for another ten steps or so, and a frightened and awestruck student approached us and quietly mumbled, 'Sir James, would it be possible to have 5 minutes of your time to show you my data?'Sir James simply put his arm around the student and said, 'Why don't we have lunch?' That story has forever affected my attitude about how important students are.

\section{Ian McGrath}

Hearing the wonderful stories of Jim's enthusiasm for helping and mentoring young scientists, I was reminded of his unrecorded influence on the concept of alpha-1L and $\mathrm{H}$ receptors. As a young editor of BJP in the mid 80s I had asked him to review a paper by Muramatsu about the then controversial subdivision of alpha-1-adrenoceptors in these precloning days. Muramatsu had made a very complicated explanation of his data and I had suggested that it might be worth a look at the even more controversial idea from Flavahan and Vanhoutte of alpha- $1 \mathrm{H}$ and $\mathrm{L}$, based on high and low affinity for antagonists. I phoned Jim for his advice and he said that he would be passing through Japan the next month and would be interested to visit Muramatsu to discuss the issue. He did so, recounting to me later that it was all very mysterious, but the side trip had been interesting. However, the idea obviously stuck since Muramatsu has published dozens of interesting papers using the $\mathrm{H}$ and $\mathrm{L}$ terminology and this has acted as an almost unsurmountable and, as yet, unresolved, challenge to almost everyone in that field. Another example of Jim encouraging the pursuit of an unconventional approach.

\section{Jean-Pierre Changeux}

Yet, at 11AM Monday (29 March) I shall spend the time to share our common sorrow and to meditate about Sir James and the exceptional relationships we shared together: in Israel for the Wolf prize when we first met, Dundee where I received from his hands the "bonnet" hit he awarded to me for the doctorate degree, also a kind visit he gave to the Académie de Médecine in Paris and the wonderful and most instructive moments we spent together among the many affectionate circumstances when we met.

I am losing a close friend I admired, it is for me a heavy loss and feel profoundly sad. 


\section{Nawazish-i-Husain Syed}

I met Dr James Black at 5th James Black conference at Crieff, Perthshire, Scotland. To me, it was the first time to see one of the Nobel laureates among ourselves, who have an immense impact on the therapeutic interventions of his time and of course long time to come. I was presenting a poster on P2X receptors characterization in rat pulmonary artery. He not only was quite aware of research on different aspects in lung pharmacology but also had a strong opinion how we the scientist should move forward without being distracted. So, his suggestions were really taken up aboard by all those who attended that event. In fact, he was a lively person and his presence was a source of encouragement to all of us who are now carrying out their duties in different parts of the world.

May his soul rest in peace and his research work keep benefiting the ailing world.

\section{Lorna Ewart}

As a Scottish pharmacology undergraduate student, I was fortunate to experience a placement at the James Black Foundation in London. My arrival there happened through a chance encounter with Sir James in Edinburgh. When I explained to him that I was studying pharmacology and that I would welcome an opportunity to experience "real life drug discovery" he welcomed me with a smile. My lasting memories of my placement at the foundation were his desire to bring closer the pharmacologists and chemists with only a swing door separating them, not miles of corridor as can often be found in pharmaceutical companies. I often re-visit in my mind this philosophy especially now that I am working within the pharmaceutical industry. It often makes me smile when people propose this thinking as a "new idea"! However, he was right. When we as pharmacologists do work more closely with chemists, great things happen and maybe it could help us in our quest to discover new blockbusters. As a student, he was a great inspiration to my career and my training at the foundation has stood me in great stead in my career. I consider myself very fortunate.

'Science goes Shopping'

Café Scientifique, Glasgow

\section{Mandy MacLean}

This event was funded by The Wellcome Trust, held in a shopping centre and involved the public, teachers and 30 school children selected from local schools. Sir James arrived early and mingled with the attendees of the meeting, chatting with the school children and getting his photo taken. They were in awe of him, but it has to be said that he was just as much in awe of them. His presentation was on drug development. It was fascinating and all the kids were spell bound. In his typical, modest manner, however, he later expressed his concern that his presentation hadn't reached them in the way he had hoped. We were able to reassure him absolutely that he had reached them and probably shaped a few careers in science as well! I myself was always very moved by the humility and humble nature of this great man.

\section{Professor C. Robin Ganellin, FRS}

I had the great fortune to collaborate with Jim for 9 years at Smith Kline \& French Laboratories whilst we tried to find an antagonist for the putative histamine $\mathrm{H}_{2}$ receptor.

I have to say that personally I found the years that I worked with Jim extraordinarily stimulating and exciting and I personally owe him a great deal. He had the extraordinary ability of asking simple but highly embarrassing questions to a chemist. Through our many conversations, most of which I recall left me floundering for answers, I began to appreciate the properties of molecules being sought by a pharmacologist. This way he started to change me from being an organic chemist towards becoming more like a medicinal chemist.

I was very sorry when he left SK\&F to go to UCL and we only managed to collaborate for a short time afterwards. However, whilst he was in UCL he initiated an undergraduate course for a BSc in Medicinal Chemistry, which is why 9 years later I was invited to take the Chair of Medicinal Chemistry.

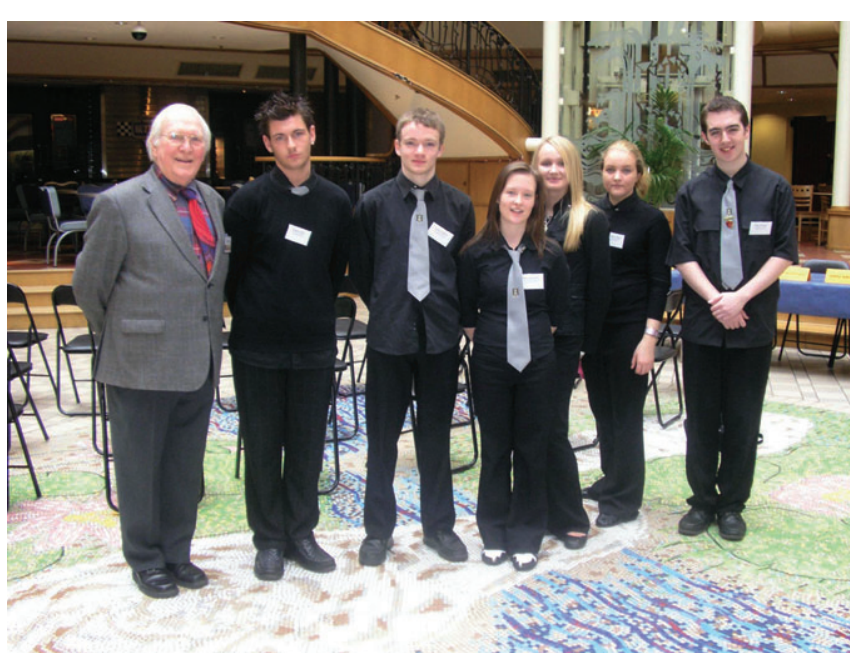

Sir James and St Thomas Aquinas High School pupils. 


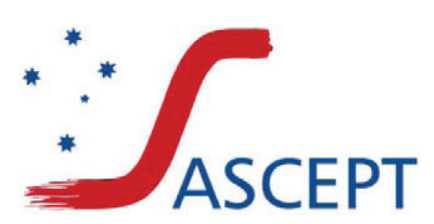

\section{Australasian Society of Clinical and Experimental Pharmacologists and Toxicologists}

24 March 2010

Dear Prof Hill,

\section{RE: Passing of Sir James Black}

On behalf of all members of the ASCEPT society, could I extend our most sincere condolences to Sir James' family, friends and colleagues.

Words in a letter such as this cannot give sufficient depth to his valued contributions over such a career.

He was an icon to so many over such a long period. His legacy will live on.

Yours sincerely,

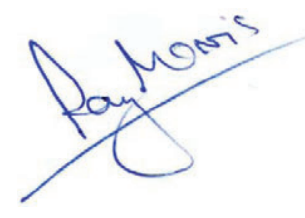

Raymond G Morris PhD

President 


\section{Personal Memories of a truly Great Scot: Professor Sir James Whyte Black}

I first met Prof. Sir James Whyte Black ("Just call me 'James'!", he laughed) a few years ago at our Cafe Scientifique - held in a shopping centre in the middle of Glasgow. It was immediately apparent that he was a very special man - one of huge intellect with a sparkle in his eye that told of his enormous sense of fun. Undaunted talking to an audience of shoppers, passers-by and schoolchildren, it was clear that this was someone who was not only truly a legend in his own lifetime, he loved his work with a passion that simply radiated from him.

It was therefore a wonderful treat but no surprise when I was asked to go down to his London home to interview him for the Scottish Television series, The Greatest Scot, broadcast last November. Who could be more fitting for the title than one of our greatest living scientists, whose contribution to medicine has earned him a knighthood, an Order of Merit, and a Nobel Prize?!

Although he was unwell and by now quite frail, what struck me most throughout the crisp, sunny morning we spent together was the joy he got from his work and also his incredible humility. He put much of his success down to "luck" and "teamwork", as well as the privilege of being given a largely free rein to pursue his own research interests and instincts (though with that mischievous giggle, one suspects he would always have worked out a way to do what he wanted to do whatever the obstacle!). It was hard not to be smitten by the gentle, smiling, modest man who sat before me and all the TV crew came away bowled away by his personality as well as his achievements.

By the time I interviewed him, I had already interviewed someone whose world had been transformed by the beta blocking drugs James had developed. I met up with the 79-year-old wrestler, David
Kidney, at the side of a wrestling ring in Dundee. Still hot and sweaty from his last round, he could barely contain his gratitude: he shook his head in wonder and with a tremor in his voice that belied his hard-man image, quietly uttered "Quite simply, that man has saved my life".

This is the effect that Professor Sir James Whyte Black had on probably hundreds of thousands of people around the world. He was a pleasure to interview, a pleasure to know and someone who was frankly inspirational to have around. The old saying that a new star is now shining brightly in the sky has never been more appropriate. We've lost a star on earth. He will be much missed.

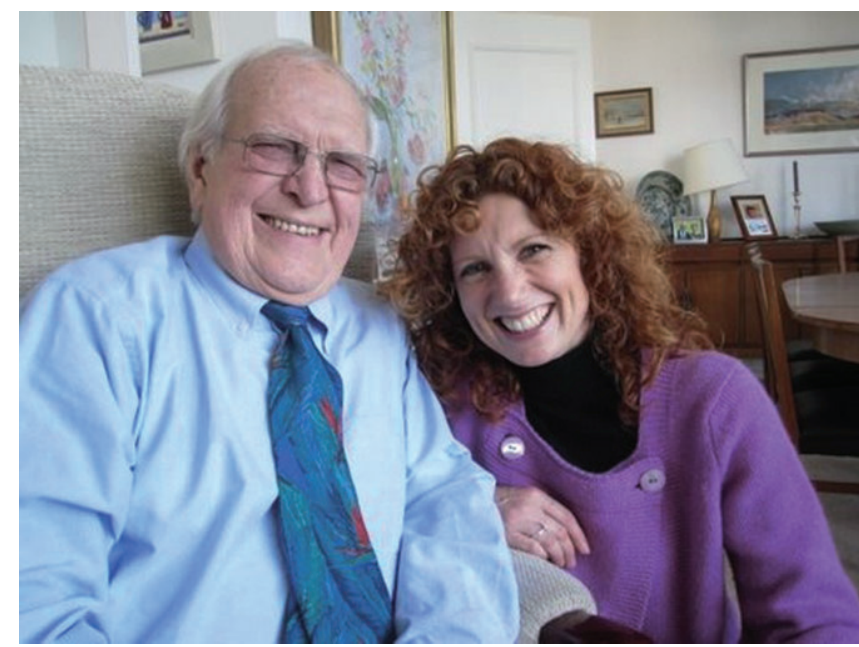

Vanessa Collingridge

Presenter: the Greatest Scot - scientists and engineers,

Scottish TV, Nov 2009

Co-host with Professor Mandy MacLean of the Glasgow Cafe Scientifique.

\section{Mentorship 'par excellence!'}

I appreciate the opportunity here to pen some of my rich learning experiences that have profoundly affected my life. I dedicate them to the memory of James Black. Most of my recollections here refer to the period of my postdoctoral fellowship, 19771978.
My first recollection in 1976 was writing to Jim from Melbourne, Australia (Baker Medical Research Institute) exploring the possibility of a post-doctoral position for 2 years in Pharmacology at UCL. He replied graciously, saying first, that if I wanted to work in whole animal cardiovascular research (my 
then expertise) and needed a salary, he could not help. But, if I had a fellowship and wanted a new experience in analytical pharmacology, please come.

I arrived on 3 January 1977. Jim wanted to meet (eyeball, he called it) the whole family (Helen and one and three year old children) as soon as we arrived. So we duly walked past Jeremy Bentham and on to Jim's office, where we got to know each other before he sent us packing for two weeks to "sort out the family's needs". A week later, I was back, ready to start. Jim offered two projects in analytical pharmacology; i) $\beta$-adrenoceptor antagonist research that pharmacologist Terry Kenakin, a postdoc from Canada was already involved with; or ii) taming the mouse isolated stomach to produce acid and then develop the assay for competitive $\mathrm{H}_{2}$-receptor antagonism. I jumped at the acid secretion assay. But before long, Jim and I met with Professor Mervyn Stone, Department of Statistics UCL to discuss assay design and analysis of my early acid secretion data. This developed into a profound collaboration that resulted in a new way of thinking, which we called the 'Clark plot'.

One extraordinary experience that year was to set up a demonstration at the pre-Christmas BPS meeting at Middlesex Hospital of three mouse stomachs to demonstrate that vagal stimulated acid secretion was blocked by the $\mathrm{H}_{2}$-receptor antagonist metiamide. Helping me with this exciting 'live' demonstration was Heinz Schild, Jim Black and Don Jenkinson. What a crowd puller! The mouse stomachs performed perfectly. Dragging my assay equipment and carbogen cylinder etc. through London streets was on reflection, a rare but beautiful experience!

Not long after I arrived at UCL, Jim Black, as field editor for the British Journal of Pharmacology received a manuscript from the editorial office with me as senior author, relating to the release of histamine from mast cells by guanethidine and like molecules. He assigned the review to a member of his Department. In a unique refereeing experience, he summoned me and the referee to this office to work through the referees comments as an 'oral viva'. The manuscript was revised and accepted. The tale piece here is that Jim always believed that the 'end game' was the responsibility of the authors. The editorial board should offer advice and obviously a quality threshold. Apart from that, publish and be damned!

Towards the end of 1977, Jim was becoming restless of UCL. The Department had little opportunities to recruit, was relatively poorly financed and Jim's reputation beckoned. He was quite direct with me. Do we move to a big Pharma in the USA, i.e. a
Merck. or what about the Wellcome Laboratories at Beckenham, where 'research is our only shareholder?' Will you come with me? That was easy. I was on an Australian Fellowship to work with Jim Black, wherever he was!

So, we moved to Beckenham in January 1978, where Sir John Vane was Research Director, and Jim was appointed Therapeutic Research Director, worldwide. We took over the library to be refurbished as the Exploratory Research Laboratory. The library was moved into port-o-cabins while I was given an almost open cheque book to equip a lab with first class bioassay equipment of the day. Jim insisted that his office should be next to the lab. What an opportunity. Jim set about to review all the research projects on site. His clear questions to project leaders were:

i) What is your assay or measurement device? Is it discriminatory, robust and specific? No" maybe" answers, just yes or no!

ii) Have you a lead target and has chemistry provided a lead molecule?

iii) Who drives the research? Is it the chemist or biologist. or better a partnership?

iv) Does the chemist insist that all chemical intermediates be assayed? Say no! Only assay the molecule agreed upfront. Do not be distracted by the intermediates and waste resources. A discipline of great importance in discovery.

After some months, Jim was clearly unpopular amongst some of the project heads but he had set a course of discipline in drug discovery that had no room for 'wishful thinking'.

As a young international postdoc, Jim insisted that I join him in regular lunchtime discussions hosted by John Vane in the 'Mansion' at Beckenham. These affairs were designed for consultants to advise the Research Director on the go, or no go development of possible therapeutics. I could not have had a better insight into the pharmaceutical development process. The clear messages were, evidence, assays, data, clinical need, safety, risk, and potential market.

There were two other standout experiences for me at Beckenham; first to see the large transport helicopters land on the hockey field taking urgent vaccines to Heathrow for donation to Africa, courtesy of Wellcome Laboratories, and second, to have my young children ride their tricycles on the grass tennis courts just weeks before the courts were the warm-up venue for Wimbledon.

At Beckenham, Jim was keen to have a pleasant distraction when first greeting people in his office. What better than a saltwater tropical fish tank ably 
looked after by Peter Randal. This was always a winner with visitors, and 'fish-feeding', a great joy for Jim.

For me, he had a number of special 'home truths' that I would like to highlight:

1. Negotiations: When I was offered the Chair at Melbourne (1992), I told the Vice Chancellor I would delay my decision pending 'negotiations' after I returned from a short visit to see Jim in London. Within minutes of seeing Jim, he asked whether I had accepted the offer. He was stunned at my 'in negotiation' answer. "Do you want the job or not?" he fired back. So I picked up the phone and accepted. He explained that to negotiate upfront could destroy trust, and from both sides you have to want to support the role in good faith. You do not really know what you need before you start a new position. Anyway, Jim's advice worked very well for me at the University and I went on to build a fabulous new facility for Pharmacology.

2. Expense Accounts: A matter of principle. When entertaining colleagues on an institution's expense account, Jim offered the following guide: Choose a level of expenditure (food/drinks) that you would be prepared to pay from your own pocket; i.e. commensurate with your income.

3. Professional Staff: He felt strongly that scientific and professional support staff should have parallel promotion levels. In the end, the Director, Lab Head etc worked in direct partnership with professional staff and the latter should be recognised and rewarded as such.

4. No Equity, No Promises: I was meeting Jim for dinner in London the night before I was presenting a possible longterm collaboration with a large Pharmaceutical company in 1987. So in true style, Jim said "and what are you going to put to them tomorrow?"

I proceeded to suggest 'say 7\%' of profit of any discovery initiated from this research after development and commercialisation. Jim proceeded to give me the 101 lecture in commercialisation! First, he said, Universities are there for discovery, innovation and dissemination of new knowledge. Pharmaceutical companies will take the discoveries, develop and commercialise. Do not confuse the two environments with different expertise. So, Universities partner with big Pharma respecting each other's territory. Universities need resources and access to molecules etc but Universities, Jim insisted, should not have large patent portfolios or commercialisation arms.

Next day I attended the interview. And what are you looking for? I replied; "First, I can make no promises. I can't predict I will discover anything, in the true nature of research. Second, I seek no equity. We agreed on publications, reporting milestones with annual reports and agreement for the next year's program of research. The Company was surprised at what I had offered and expected. This was a different relationship. I and my research group at the Baker Institute and Melbourne University benefited from 10 years generous research support based on these simple principles of no promises, no equity.

\section{Personal Qualities:}

It is often said that scientists have to be curious. But as Judson said, this word is too mild by far - a word for 'infants'.

For Jim, when he tackled a problem, the curiosity rapidly escalates to having, as Sir Peter Medawar said, an 'acute discomfort at incomprehension', even a 'rage to know'. But Jim is a generous and caring gentleman. He wants to share his rage to know and many of his students and colleagues have been infected by Jim's 'acute discomfort at incomprehension.'

Jim has also been spreading his infection to the Molecular Biologists with his discomfort. In a foreword in the 'Logic of Life', Jim challenged the Physiologists to assert their integrative approach to problem solving in modern biology. He had been asked by a British newspaper to give his view on the future of his science. The characteristic, provocative reply was "the progressive triumph of physiology over molecular biology"

People often ask what he was really like to work with, this restless dynamo, or flying Scotsman. Let me try to describe it; you bring in traces from the recorder or whatever. First the intense eyes scan the data, questions on method, controls, stability etc, fire back like grapeshot. Then the inevitable, "Well young Angus, what do you make of it?" You mumble something. You watch the eyes. They start to twinkle. The face begins to fill with a bursting glow as he rocks back in the chair killing himself with laughter. He has an idea or conclusion drawn from way out in right field.

How can he possibly have drawn that conclusion from that data, you ask. That is when you learn of the enormous breadth of this man's knowledge, his capacity for lateral thinking, and the mischief. As the scene returns to reality, Jim would say: "Let's enjoy this magical moment for what it is. We have of course 95\% chance of being wrong!" Einstein said of such a moment in scientific endeavour, 'only those who have experienced it can understand it!' 
The Private Man:

I don't wish to dwell on the subject but just to say, Jim was not about showmanship. You will not see any evidence of the extraordinary number of honorary degrees, awards, plaques, gold trophies etc in the office or home. I did ask once, when visiting his home. Eventually, after much youthful persistence he reluctantly agreed. He disappeared for 5 minutes and returned with a large shoe box, tipped its contents all over the lounge room floor. 'Happy?', he asked! He added that these honours would always be received graciously on behalf of science but I suggest with much uneasiness, under the spotlight.

So, in summarising Jim's special qualities may I suggest:-

- His infectious 'rage to know'

- His energy. Just try to keep up with Jim as he raced up stairs two at a time before his hips called 'enough!'

- His use of language, leaving most of us groping for the Oxford!

- His sense of fair play

- His discipline and rigor in every aspect of science and, in a complementary way, his unwavering persistence to tackle and stamp out 'sloppy thinking'.

He was in every aspect a delight to be around. A true scientist's scientist. We never 'mused' the time away.
His mind was forever racing. The sharp intellect had a sound analysis for any topic. As you can read, I was a youthful convert.

In conclusion, I am forever grateful to have had the incredible fortune to work and learn from James Black. Probably his greatest influence on me was to say, in a contrary view to others, as to whether I should accept a leading position in the UK or USA versus returning to Australia - "Return home; they sponsored you to come. You owe Australia in return".

I cannot remember any advice freely given by Jim that has not, when tested, turned up trumps. What a record!

To Rona and Stephanie may I pay my deepest respects, as I cherish the memories of wonderful times we shared together with Jim.

\section{Conflicts of interest}

The authors have declared no potential conflicts.

Professor James A. Angus Dean, Faculty of Medicine, Dentistry and Health Sciences,

The University of Melbourne. jamesaa@unimelb.edu.au 